\title{
Antibody Response to a Live-Modified Virus Vaccine Against Bovine Viral Diarrhoea in Dairy Cattle in Field Trial
}

\section{Małgorzata Dorota Klimowicz-Bodys}

Wroclaw University of Environmental and Life Sciences https://orcid.org/0000-0002-8596-0822

Katarzyna Ploneczka-Janeczko

Wroclaw University of Environmental and Life Sciences: Uniwersytet Przyrodniczy we Wroclawiu

Michał Czopowicz

Warsaw University of Life Sciences: Szkola Glowna Gospodarstwa Wiejskiego w Warszawie

\section{Mirosław P Polak}

National Veterinary Institute - National Research Institute: Panstwowy Instytut Weterynaryjny -

Panstwowy Instytut Badawczy w Pulawach

\section{Radosław Pruban}

Veterinary Practice Zwierzak

Krzysztof Rypula ( $\nabla$ krzysztof.rypula@upwr.edu.pl)

Wroclaw University of Environmental and Life Sciences https://orcid.org/0000-0003-3884-4834

\section{Research article}

Keywords: BVDV, Dairy cattle, life-modified virus vaccine, Vaccination

Posted Date: December 10th, 2020

DOl: https://doi.org/10.21203/rs.3.rs-123021/v1

License: (c) (1) This work is licensed under a Creative Commons Attribution 4.0 International License.

Read Full License 


\section{Abstract}

Background: The objective of the study was to evaluate of the long-term antibody response of dairy cows to a single dose of a commercial modified-live virus (MLV) vaccine against bovine viral diarrhoea (Mucosiffa ${ }^{\circledR}$ CEVA Animal Health, Spain). The study was carried out in a dairy cattle herd counting 290 animals negative for BVDV. The vaccination was implemented in calves from the age of 2 months.

Twelve adult lactating cows were randomly selected before study, and blood samples were collected right before the vaccination and then 12 times at 1-month intervals. The serum samples were screened using virus neutralization test (VNT) and ELISA.

Results: Both tests showed that antibody titers increased significantly in all animals within the first month post vaccination, and continued to increase until the second (VNT) and third (ELISA) month post vaccination. Antibody titers remained high and stable until the end of the study. Moreover, cows did not show any adverse reactions or clinical symptoms of disease.

Conclusion: The results of this study indicated that the administration of one dose MLV vaccine was able to stimulate long-lasting (12-months) and strong antibody response in all vaccinated cows.

\section{Background}

Bovine viral diarrhoea virus 1 (BVDV-1) and bovine viral diarrhoea virus 2 (BVDV-2), (according to the new taxonomic classification referred to as Pestivitus A and Pestivius B, respectively) are small singlestranded positive-sense RNA viruses, classified in the genus Pestivirus and the Flaviviridae family [1]. These viruses cause an infectious and contagious disease in cattle and wild ruminants, bovine viral diarrhoea (BVD), characterized by various clinical signs relating to the gastrointestinal and respiratory systems. Viral infection induces immunosuppression and reproductive disorders as well. BVD causes large economic losses due to forced culling, morbidity and mortality $[2,3]$. The impact of BVDV depends on its virulence, the time of infection, herd immunity, level of disease prevalence, herd production level and concomitant infections $[4,5]$.

BVDV-1 is endemic in many regions of the world including Poland [6, 7]. BVDV infection has been found in $30-70 \%$ of cattle dairy herds $[8,9]$ with a high percentage of BVDV-positive animals, especially in large dairy herds [10] in Poland. BVDV-2 was reported only once in 2014 [11]. The vaccination with modifiedlive virus (MLV) is currently a well-accepted procedure in the BVD control programs in most of European countries and is considered a complementary biosecurity tool in countries with high BVD prevalence, to prevent infection and re-infections in cattle herds [12].

The vaccination has provided protection against BVDV that has been effective from a herd perspective, reduced clinical signs of disease and economic losses $[4,5]$ although vaccines could have limited durations of immunity [13]. The value of vaccination is that it increases herd immunity so that the incidence of infection of BVDV and the birth of PI calves are reduced in the herd as a whole [14]. 
Compared to MLV vaccines, inactivate (killed) vaccines contain viral antigen(s) incapable of replication, thus lowering the risk of adverse effects in vaccinates.

A main disadvantage of inactivated vaccines is the need for initial vaccinates to be dosed several times

to achieve protective antibody levels in the animal [15]. However, detailed data on the long-term antibody response to a single vaccination with a commercial MLV vaccine are scarce.

This study aimed to evaluate of the long-term antibody response of dairy cows to a single dose of a commercial modified-life virus (MLV) vaccine against BVD.

\section{Results}

At the beginning of the study, the 12 cows were seronegative for BVDV and negative for BVDV antigen and remaining seronegative during the study. All newborn calves subsequently tested (as part of the BVDV monitoring program) were negative.

All cows showed serological response to vaccination in both VNT and ELISA one month after administration of one dose of a live-modified vaccine. Then, antibody titers tended to increase significantly compared to the previous measurement on 2nd in VNT (Fig. 1) and 2nd and 3rd in ELISA (Fig. 2). The antibody titers remained high and stable until the end of the study. VNT titers were significantly positively correlated to ELISA results at all time-points except for the 9th month (Table 1).

Animals remained healthy throughout the study. No adverse reactions were observed following vaccination and no clinical signs of BVD disease were noted.

\section{Discussion}

The control of BVDV is based on strict biosecurity, eradication efforts (identification and removal of PI cattle) and vaccination, or a combination of these factors. One of the main goals of vaccination against BVDV is to prevent persistent infection [18].

The aim of this study was to investigate the effectiveness of live-attenuated (MLV) monovalent vaccine against BVDV, licensed for sale in Poland. Our study showed that one dose of a commercial MLV vaccine ensures protective level of antibodies in all vaccinated animals, which emerges as soon as one month after vaccination and remains stable for at least a year. The VNT titers of 20 which is considered as protective $[19,20]$ was reached in all cows 2 months after vaccination and it was maintained for the entire study period. The results of VNT were strongly positively correlated with the results of ELISA, which indicates that both tests yield consistent results.

In our study a neutralizing antibody response was detected in vaccinated animals one month after vaccination, reaching a peak of $4.3 \log 2$. The antibody titer was significantly higher $(5.8 \log 2, p<0.05)$ a month later. It was reported strong and durable seroneutralizing response one month after Mucosiffa ${ }^{\circledR}$ 
vaccine administration. Moreover no virus was detected in the foetus, no viremia (cellular and plasmatic) and no leucopenia/lymphocytopenia were observed after challenge of non-cytopathic BVDV$1 \mathrm{f} 22146 /$ Han81 strain [21]. From the other hand the vaccination with Mucosiffa ${ }^{\circledR}$ vaccine could induce an adequate level of neutralizing antibodies to BVDV-2 (seroconversion) and produce protection against an experimental infection with BVDV-2 [22]. The Bovela ${ }^{\circledR}$ vaccine containing both BVDV types 1 and 2 strains induced VN antibody titers to BVDV-1 similar to the field strain FSV B90 BVDV-2 in 5th and 6th week post vaccination. However the antibody titers to BVDV-2 were significantly lower $(p<0.05)$ for Bovela ${ }^{\circledR}$ group than for the FSV group in 5th, 6 th and 7th week after vaccinations [23]. From the other hand the seroneutralizing response resulting from vaccination with MLV vaccine, are generally lower than those resulting from natural exposure but follow similar development and decay curves [24].

Selection of BVDV vaccines is based on ability to protect against acute infection and to protect the developing foetus [25]. It was demonstrated that live BVDV vaccines are able to pass the placental barrier [26] and could replicate in the foetus [27] which provides active immunization against transplacental BVDV infection of the foetus. However, administration of live-attenuated vaccine has not provided $100 \%$ protection of the foetus [28].

Although vaccination does not always induce measurable antibodies in all individuals, BVDV vaccination increases herd immunity, so that the incidence of clinical disease and the birth of PI animals are reduced. The number of cows which we enrolled in our study provides very trustworthy information that at least three-fourths of cows in this herd mounted similar serological response to the vaccination. Moreover, if exposure occurs vaccination will also reduce the spread of BVD virus in the herd [14]. Independently from the vaccination the regular monitoring of the farms should be, undertaken as part of the BVDV control program.

The ability of MLV vaccines to induce an adequate neutralizing antibody titers is mainly associated with reduction of viremia and viral shedding. However, the use of live-attenuated vaccines have been limited due to the use of BVDV contaminated fetal bovine sera (FBS). These live vaccines have the potential to increase the transmission of the virus and cause disease outbreaks in susceptible animals [14]. A raw FBS testing for the presence of BVDV before Gamma irradiation is demanded by most biopharmaceutical companies, which is required by the EU regulation Directive for Pharmaceutical Raw Material of Bovine Origin (EMEA-CPMP-BWP-1793-02). However, some FBS producers that want to avoid the risk that their products will not be approved for use in the production of bioproducts irradiate raw FBS prior to testing for BVDV, without disclosing this information to the biopharmaceutical companies [29]. Antos at al. [30] examined commercial FBS available on the local Polish market and in immunoprophylaxis and diagnostics in Poland. Only one serum showed the presence of an infectious virus and was contaminated with all three species of BVDV. According to the declaration of the producer, it was an inactivated vaccine against IBR.

\section{Conclusions}


Both live-atenuated and inactivated vaccines are used to protect cattle against BVDV infection. Each type of vaccine has its own advantages and disadvantages. The main advantage of a modified-live virus vaccine is the stimulation of long-term protection, reduction of viremia and viral shedding. However, MLV vaccine may increase the risk of adverse effects in vaccinated animals. Hence, there is a need for further research and the development of safer and more effective vaccines that, in addition to protection, also differentiate between vaccinated and infected animals.

\section{Methods}

\section{Animals}

The vaccination and sample collection took place at dairy farm in Greater Poland voivodeship, between February 2018 and May 2019. This herd had been involved in a voluntary BVD control program and had all of their animals previously tested for BVDV (IDEXX BVDV Total Ab Test, Scandinavia AB, Sweden) using ELISA. The herd counted 290 heads. Infections with rotavirus, coronavirus and Cryptosporidium parvum in calves and Streptococcus uberis in adult cows had been previously detected in the herd. All animals were free from bovine herpesvirus type 1 (BHV-1). The planned study had character of field research.

Twelve adult lactating dairy cows ( 1 st, 2 nd and 3rd lactation) from this herd were randomly selected for the study using simple random method. This sample size was chosen to ensure at least $95 \%$ certainty (level of confidence) that at least one seronegative cow would have been detected if less than $75 \%$ of vaccinated cows had seroconverted after vaccination. The following formula was used for calculation of the samples size [16]:

$\mathrm{n}=\left\{1-(1-\mathrm{P})^{\wedge}(1 / \mathrm{d})\right\} \times(\mathrm{N}-\mathrm{d} / 2)+1$

where:

$\mathrm{n}$ - required sample size

$\mathrm{N}$ - herd size (290)

$d$ - minimum expected number of cows which did not seroconvert after vaccination (25\%)

\section{Vaccination}

The monovalent commercial vaccine Mucosiffa ${ }^{\circledR}$ (CEVA Animal Health, Spain) containing liveattenuated, cytopathic BVDV-1a strain OregonC 24 strain at a minimum titer $10^{3.5} \mathrm{TCID}_{50}$ and maximum titer $10^{6} \mathrm{TCID}_{50}$ per $2 \mathrm{ml}$ dose was used. The vaccination was introduced in March 2018. The vaccinations were implemented in calves from the age of 2 months without a booster vaccination. The next vaccination was performed one year later.

\section{Sample collection}


Blood samples were taken from the jugular vein right before the vaccination (day 0 ) and then 12 times at one-month intervals. Blood was left at room temperature for 8-12 $\mathrm{h}$ after collection, and centrifuged. Then, serum samples were frozen at $-80^{\circ} \mathrm{C}$ and transported directly

to the Diagnostic Laboratory EPI-VET of Faculty of Veterinary Medicine, Wroclaw, Poland for ELISA and to the Diagnostic Laboratory of Department of Virology of National Veterinary Research Institute, Pulawy, Poland for VNT.

\section{Detection of antigen}

Extraction of viral nucleic acid from vaccines, and potentially infected cell culture, and sera of 12 cows enrolled in the study was performed with a QIAamp Viral RNA Mini Kit (Qiagen, Hilden, Germany) according to the manufacturer's spin protocol. Extracted RNA samples were stored at $-80^{\circ} \mathrm{C}$ prior to PCR tests. The samples were tested individually. The cows were tested for BVDV antigen using a commercial ELISA (BVDV Ag/Serum Plus, IDEXX, Schwizerland) and for the BVDV infection using qPCR with the primers which represented $100 \%$ homology with over $95 \%$ of the NCBI database reference sequences available at the time of design (genesig ${ }^{\circledR}$ qPCR Kit for Bovine Viral Diarrhoea Virus and Border Virus, Primerdesign, UK). The ELISA for antigen was performed according to manufacturer's manual with the cut-off set at optical density of 0.3 .

\section{Virus neutralization test (VNT)}

VNT was done in two-fold serial dilutions (from 1:5 to 1:640) of serum samples from all cow. All serum samples were tested for neutralizing antibodies against cytopathic (cp) BVDV-1a strain Singer use at the concentration of $100 \mathrm{TCID}_{50}$. Viral controls included 100,10,1 and $0.1 \mathrm{TCID}_{50}$. Cell culture control was MDBK without BVDV infection. The antibody titer was read after 4 days of incubation at $37^{\circ} \mathrm{C}$ and $5 \%$ $\mathrm{CO}_{2}$ atmosphere and expressed as the reciprocal of the highest dilution inhibiting cytopathic effect in $50 \%$ of dilution wells. The titer was presented as log2 value.

\section{ELISA}

Serum samples were tested with Erns Ab ELISA (BVDV Total Ab Test, IDEXX, Schwizerland). Samples with sample-to-positive control ratio ( $\mathrm{S} / \mathrm{P} \%$ ) values higher than or equal to $30 \%$ were classified as positive, those with values less than $20 \%$ were considered negative and samples with values Ranging from $20-$ $29 \%$ were considered inconclusive. The ELISA was performed according to the manufacturer's manual at an absorbance of $450 \mathrm{~nm}$ wavelength. The test is $96.7 \%$ sensitive and $97.1 \%$ specific compared with VNT [17].

\section{Statistical analysis}

Antibody titers were presented as the median, interquartile range (IQR) and range, and compared between consecutive months using the Friedman test and Wilcoxon signed-rank test with Bonferroni correction for 
familywise error. A significance level (a) was set at 0.05 . Statistical analysis was performed in TIBCO Statistica 13.3.0 (TIBCO Software Inc., Palo Alto, CA, USA).

\section{Abbreviations}

MLV

modified-life virus

BVD

bovine viral diarrhoea

BVDV

bovine viral diarrhoea virus

$\mathrm{PI}$

persistently infected

BHV

bovine herpesvirus

\section{Declarations}

- Ethics approval and consent to participate:

The samples used in this study originally came from the samples used as a material for a routine diagnostic of the health status of dairy cattle herds and the owner provided informed consent prior to initiation of the study. The II Local Ethical Committee for Animal Experiments, Wroclaw, Poland, qualified the study as research that did not require ethics committee approval.

- Consent for publication: Not applicable

- Availability of data and materials:

The datasets used and/or analyzed during the current study are available from the corresponding author on reasonable request.

- Competing Interests:

The authors declare that they have no competing interests.

\section{- Funding:}

There has been no significant financial support for this work that could have influenced its outcome.

- Authors' contribution:

All authors of this research paper have directly participated in the planning abd/or execution and/or analysis of this study. MKB analyzed the data drafted the manuscript. KPJ revised the manuscript. MC 
made statistical analysis and interpreted the data. MP participated in the study design. RP collected blood samples. KR conceived the study and designed the work.

All authors read and approved the final manuscript

\section{- Acknowledgements:}

We want to thank the technicians from the Diagnostic Laboratory EPI-VET of Faculty of Veterinary Medicine in Wroclaw, and the Diagnostic Laboratory of Department of Virology of National Veterinary Research Institute in Pulawy for ELISA and VST performed in this study and Dr Giorgio Valla from CEVA Animal Health for help in redaction of manuscript.

\section{- Authors' information:}

Małgorzata D. Klimowicz-Bodys; https://orcid.org/0000-0002-8596-0822

Katarzyna Płoneczka-Janeczko; https://orcid.org/0000-0002-7621-4449

Michał Czopowicz; https://orcid.org/0000-0002-4238-8360

Mirosław P. Polak; https://orcid.org/0000-0002-0909-9751

Krzysztof Rypuła; https://orcid.org/0000-0003-3884-4834

\section{References}

1. International Committee on Taxonomy of Viruses (ICTV). Flaviviridae. Virus taxonomy: the classification and nomenclature of viruses. Report of ICTV. Available from URL: ; 2019.

2. Simmonds P, Becher P, Bukh J, Gould EA, Meyers G, Monath T, Muerhoff S, Pletnev A, R R-H, Smith DB, Stapleton JT, ICTV Report Consortium. ICTV Virus Taxonomy Profile, Flaviviridae. J Gen Virol. 2017;98:2-3. https://doi.org/10.1099/jgv.0.000672.

3. Houe H. Economic impact of BVDV infection in dairies. Biologicals. 2003. https://doi.org/10.1016/S1045-1056(03)00030-7. 31: 137 - 43.

4. Rodning PS, Givens DM, Marley DSM, Zhang Y, Riddell PK, Galik KP, Hathcock TL, Gard JA, Prevatt JW, Owsley FW. Reproductive and economic impact following controlled introduction of cattle persistently infected with bovine viral diarrhea virus into a naïve group of heifers. Therio. 2012;78:1508-16.

5. https://doi.org/10.1016/j.theriogenology.2012.05.031.

6. Stott AW, Humphry RW, Gunn GJ. Modelling the effects of previous infection and re-infection on the costs of bovine viral diarrhoea outbreaks in beef herds. Vet J. 2010;185:138-43. https://doi.org/10.1016/j.tvjl.2009.05.020. 
7. Kuta A, Polak MP, Larska M, Żmudziński JF. Predominance of bovine viral diarrhea virus $1 \mathrm{~b}$ and $1 \mathrm{~d}$ subtypes during eight years of survey in Poland. Vet Microbiol. 2013;166:639-44. https://doi.org/10.1016/j.vetmic.2013.07.002.

8. Mirosław P, Polak M. Increased genetic variation of bovine viral diarrhea virus in dairy cattle in Poland. BMC Vet Res. 2019;15:278. https://doi.org/10.1186/s12917-019-2029-z.

9. Kuta A, Polak MP, Larska M, Żmudziński JF. Monitoring of Bovine Viral Diarrhoea Virus (BVDV) infection in Polish dairy herds using bulk tank milk samples. Bulletin of the Veterinary Institute in Pulawy. 2013;57:149-56. https://doi.org/10.2478/bvip-2013-0028.

10. Rypuła K, Ploneczka-Janeczko K, Czopowicz M, Klimowicz-Bodys MD, Shabunin S, Siegwalt G. Occurrence of BVDV infection and the presence of potential risk factors in dairy cattle herds in Poland. Animals. 2020;10:230. https://doi.org/10.3390/ani10020230.

11. Rypuła K, Kumala A, Kaba J, Płoneczko-Janeczko K, Wojewoda-Kotwica B, Mazurkiewicz M. Epidemiological aspects of BVDV infections in dairy cattle herds in Poland. Med Wet. 2010: 66, 684-7 (In Polish) http://www.medycynawet.edu.pl/archives/161-summary-2010/summary-2010-10/430summarymedycyna-wet-66-10-684-687-2010.

12. Polak MP, Kuta A, Rybałtowski W, Rola J, Larska M, Żmudziński JF. First report of bovine viral diarrhoea virus-2 infection in cattle in Poland. Vet J. 2014;202:643-5. https://doi.org/10.1016/j.tvjl.2014.09.026.

13. Moennig V, Houe H, Lindberg A. BVD control in Europe: current status and perspectives. Anim Health Res Rev. 2005;6:63-74. https://doi.org/10.1079/AHR2005102.

14. Fulton RW. Impact of species and subgenotypes of bovine viral diarrhea virus on control by vaccination. Anim Health Res Rev. 2015;16:40-54. https://doi.org/10.1017/S1466252315000079.

15. Ridpath JF. Immunology of BVDV vaccines. Biologicals. 2013;41:14-9. https://doi.org/10.1016/j.biologicals.2012.07.003.

16. Newcomer BW, Chamorro MF, Walz PH. Vaccination of cattle against bovine viral diarrhea virus. Vet Microbiol. 2017;206:78-83. https://doi.org/10.1016/j.vetmic.2017.04.003.

17. Surveys. In: Thrusfield M., Christley R., editors. Veterinary Epidemiology, 4th ed. John Wiley \& Sons Ltd. 2018, $270-96$.

18. Lanyon SR, Anderson ML, Bergman E, Reichel MP. Validation and evaluation of a commercially available ELISA for the detection of antibodies specific to bovine viral diarrhoea virus (bovine pestivirus). Aust Vet J. 2013;91:52-6. https://doi.org/10.1111/j.1751-0813.2012.01010.x.

19. Newcomer BW, Walz PH, Givens MD. Efficacy of bovine viral diarrhea virus vaccination to prevent reproductive disease: a meta-analysis. Therio. 2015;83:360-5. https://doi.org/10.1016/j.theriogenology.2014.09.028.

20. Ridpath JF, Neill JD, Frey M, Landgraf JG. Phylogenetic, antigenic and clinical characterization of type 2 BVDV from North America. Vet Microbiol. 2000;77:145-55. https://doi.org/10.1016/S03781135(00)00271-6. 
21. Sozzi E, Righi C, Boldini M, Bazzucchi M, Pezzoni G, Gradassi M, Petrini S, Lelli D, Ventura G, Pierini I, Moreno A, Brocchi E, Lavazza A, De Mia GM. Cross-Reactivity Antibody Response after Vaccination with Modified Live and Killed Bovine Viral Diarrhoea Virus (BVD). Vaccines. 2020;8:374. https://doi.org/10.3390/vaccines8030374.

22. Meyer G, Deplanche M, Roux D, Moulignie M, Picard-Hagen N, Lyazrhi F, Raboisson D, Mathevet P, Schelcher F. Fetal protection against bovine viral diarrhoea type 1 virus infection after one administration of a live-attenuated vaccine. Vet J. 2012;192:242-5. https://doi.org/10.1016/j.tvjl.2011.05.011.

23. Thibault JC, Hamers C, Couvreur B, Letellier C, Dehan P, Brun A, Fischer L, Pastoret PP, Kerkhofs P. Efficacy of vaccination with a BVDV1 live-vaccine an a BVDV1 inactivated vaccine against a BVDV2 challenge. Tierärztliche Umschau. 2004; 59; 139 - 43.

24. Platt R, KesI L, Guidarini Ch, Wang Ch, Roth JA. Comparison of humoral and T-cell-mediated immune responses to a single dose of Bovela ${ }^{\circledR}$ live double deleted BVDV vaccine or to a field BVDV strain. Vet Immun Immunopath. 2017;187:20-7. https://doi.org/10.1016/j.vetimm.2017.03.003.

25. Cortese VS, Whittaker R, Ellis J, Ridpath JF, Bolin SR. Specificity and duration of neutralizing antibodies induced in healthy cattle after administration of a modified-life virus vaccine against bovine viral diarrhea. Am J Vet Res. 1998;59:848-50. https://pubmed.ncbi.nlm.nih.gov/9659549/.

26. Walz PH, Riddel KP, Newcomer BW, Neil JD, Falkenberg SM, Cortese VS, Scruggs DW, Short TH. Comparison of reproductive protection against bovine viral diarrhea virus provided by multivalent viral vaccines containing inactivated fractions of bovine viral diarrhea virus 1 and 2 . Vaccine. 2018;36:3853-60. https://doi.org/10.1016/j.vaccine.2018.04.005.

27. van Oirschot JT, Bruschke CJM, van Rijn PA. Vaccination of cattle against bovine viral diarrhoea. Vet Microbiol. 1999;64:169-83.

28. Meyers G, Ege A, Fetzer C, von Freyburg M, Elbers K, Carr V, Prentice H, Charleston B, Schürmann EM. Bovine viral diarrhea virus: prevention of persistent fetal infection by a combination of two mutations affecting Erns RNase and Npro protease. J Virol. 2007;81:3327-38. https://doi.org/10.1128/JVI.02372-06.

29. Walz PH, Givens MD, Rodning S, Riddel KPK, Brodersen BW, Scruggs D. Evaluation of reproductive protection against bovine viral diarrhea virus and bovine Herpesvirus 1 afforded by annual vaccination with modified-life viral or combination modified-live viral vaccine. Vaccine. 2017;35:1046-54. https://doi.org/10.1016/j.vaccine.2017.01.006.

30. Hawkes PW. Fetal Bovine Serum (FBS). Irradiation Working Group. The harmonization and standardization of irradiation procedures for fetal bovine serum (FBS) https://www.biowest.net; 2016 [accessed 20 May 2016].

31. Antos A, Rola J, Bednarski M, Krzysiak MK, Kęsik-Maliszewska J, Larska M. Is contamination of bovine-sourced material with bovine viral diarrhea virus still a problem in countries with ongoing eradication campaigns? Ann Anim Sci. 2020. https://doi.org/10.2478/aoas-2020-0056. 


\section{Tables}

Table 1. Antibody titers in VNT and sample-to-positive control ratio in ELISA during 12 months post vaccination. 


\begin{tabular}{|c|c|c|c|c|c|}
\hline $\begin{array}{l}\text { Serological } \\
\text { testing } \\
\text { (month) }\end{array}$ & $\begin{array}{l}\text { VNT } \\
\text { [log2 } \\
\text { transformed } \\
\text { titer] }\end{array}$ & $\begin{array}{l}\text { Significance of } \\
\text { an increment } \\
\text { compared to } \\
\text { the previous } \\
\text { testing }(p)\end{array}$ & $\begin{array}{l}\text { ELISA } \\
\text { [S/P\%] }\end{array}$ & $\begin{array}{l}\text { Significance of an } \\
\text { increment compared to } \\
\text { the previous testing }(p)\end{array}$ & $\begin{array}{l}\text { Correlation } \\
\text { between } \\
\text { VNT and } \\
\text { ELISA } \\
\text { (Rs, p-value) }\end{array}$ \\
\hline 0 & 0 & - & 0 & - & - \\
\hline 1 & $\begin{array}{l}4.3,2.8-4.3 \\
(2.3-6.3)\end{array}$ & $0.009^{*}$ & $\begin{array}{l}45,23- \\
63(17- \\
164)\end{array}$ & $0.009^{*}$ & $\begin{array}{l}0.91 \\
p<0.001^{*}\end{array}$ \\
\hline 2 & $\begin{array}{l}5.8,5.3-6.3 \\
(4.3-8.3)\end{array}$ & $0.014^{*}$ & $\begin{array}{l}87,63- \\
111 \\
(16- \\
146)\end{array}$ & $0.030^{*}$ & $\begin{array}{l}0.88 \\
p<0.001^{*}\end{array}$ \\
\hline 3 & $\begin{array}{l}\text { 6.3, 5.3-7.3 } \\
(5.3-8.3)\end{array}$ & ns & $\begin{array}{l}107 \\
92-135 \\
(60- \\
174)\end{array}$ & $0.030^{*}$ & $\begin{array}{l}0.90 \\
p<0.001^{*}\end{array}$ \\
\hline 4 & $\begin{array}{l}\text { 6.8, 6.3-7.8 } \\
(5.3-8.3)\end{array}$ & ns & $\begin{array}{l}108 \\
100- \\
138 \\
(72- \\
173)\end{array}$ & ns & $\begin{array}{l}0.79 \\
p=0.003^{*}\end{array}$ \\
\hline 5 & $\begin{array}{l}\text { 6.8, 6.3-7.8 } \\
(5.3-8.3)\end{array}$ & ns & $\begin{array}{l}114 \\
99-130 \\
(70- \\
169)\end{array}$ & ns & $\begin{array}{l}0.74, \\
p=0.006^{*}\end{array}$ \\
\hline 6 & $\begin{array}{l}\text { 6.8, 6.3-7.3 } \\
(5.3-8.3)\end{array}$ & ns & $\begin{array}{l}123 \\
93-138 \\
(69- \\
169)\end{array}$ & ns & $\begin{array}{l}0.84, \\
p=0.001^{*}\end{array}$ \\
\hline 7 & $\begin{array}{l}\text { 6.8, 6.3-8.3 } \\
(5.3-9.3)\end{array}$ & ns & $\begin{array}{l}122 \\
107- \\
131 \\
(79- \\
148)\end{array}$ & ns & $\begin{array}{l}0.82 \\
p=0.001^{*}\end{array}$ \\
\hline 8 & $\begin{array}{l}\text { 6.8, 6.3-8.3 } \\
(5.3-9.3)\end{array}$ & $\mathrm{ns}$ & $\begin{array}{l}104 \\
101- \\
135 \\
(78- \\
168)\end{array}$ & ns & $\begin{array}{l}0.91 \\
p<0.001^{*}\end{array}$ \\
\hline 9 & $\begin{array}{l}\text { 6.3, 5.3-7.3 } \\
(5.3-8.3)\end{array}$ & ns & $\begin{array}{l}136 \\
96-161 \\
(68- \\
173)\end{array}$ & ns & $\begin{array}{l}0.30 \\
p=0.353\end{array}$ \\
\hline 10 & $\begin{array}{l}6.3,5.3-6.3 \\
(4.3-8.3)\end{array}$ & ns & $\begin{array}{l}117 \\
97-140 \\
(51- \\
168)\end{array}$ & ns & $\begin{array}{l}0.90 \\
p<0.001^{*}\end{array}$ \\
\hline
\end{tabular}




\begin{tabular}{|c|c|c|c|c|c|}
\hline 11 & $\begin{array}{l}6.3,5.3-7.3 \\
(5.3-8.3)\end{array}$ & ns & $\begin{array}{l}132 \\
94-137 \\
(51- \\
159)\end{array}$ & ns & $\begin{array}{l}0.70 \\
p=0.011^{*}\end{array}$ \\
\hline 12 & $\begin{array}{l}5.8,5.3-6.3 \\
(5.3-9.3)\end{array}$ & ns & $\begin{array}{l}128 \\
113- \\
139 \\
(78- \\
184)\end{array}$ & ns & $\begin{array}{l}0.92 \\
p<0.001^{*}\end{array}$ \\
\hline
\end{tabular}

Antibody titers in VNT (presented as log base 2) and sample-to-positive control ratio (S/P\%) in indirect ELISA are presented as the median, interquartile range (IQR) and range.

* - statistically significant at $a=0.05$

ns - non-significant

Figures

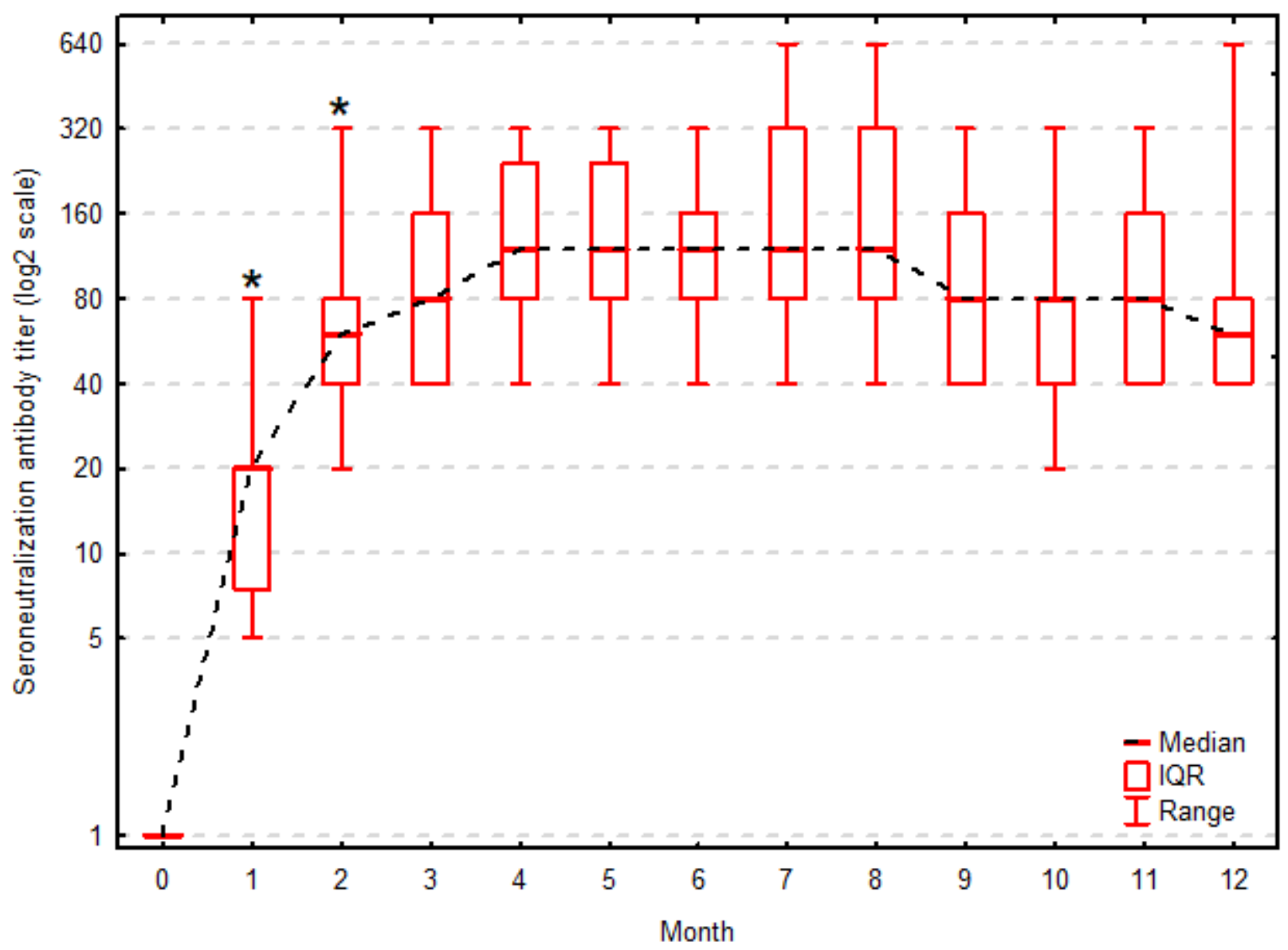


Figure 1

Antibody titers in virus neutralization test during 12 months post vaccination. Antibody titers (on log base 2 transformed scale) are presented as the median, interquartile range (IQR) and range. Asterisk (*) indicates statistically significant increase of the titer compared to the previous one.

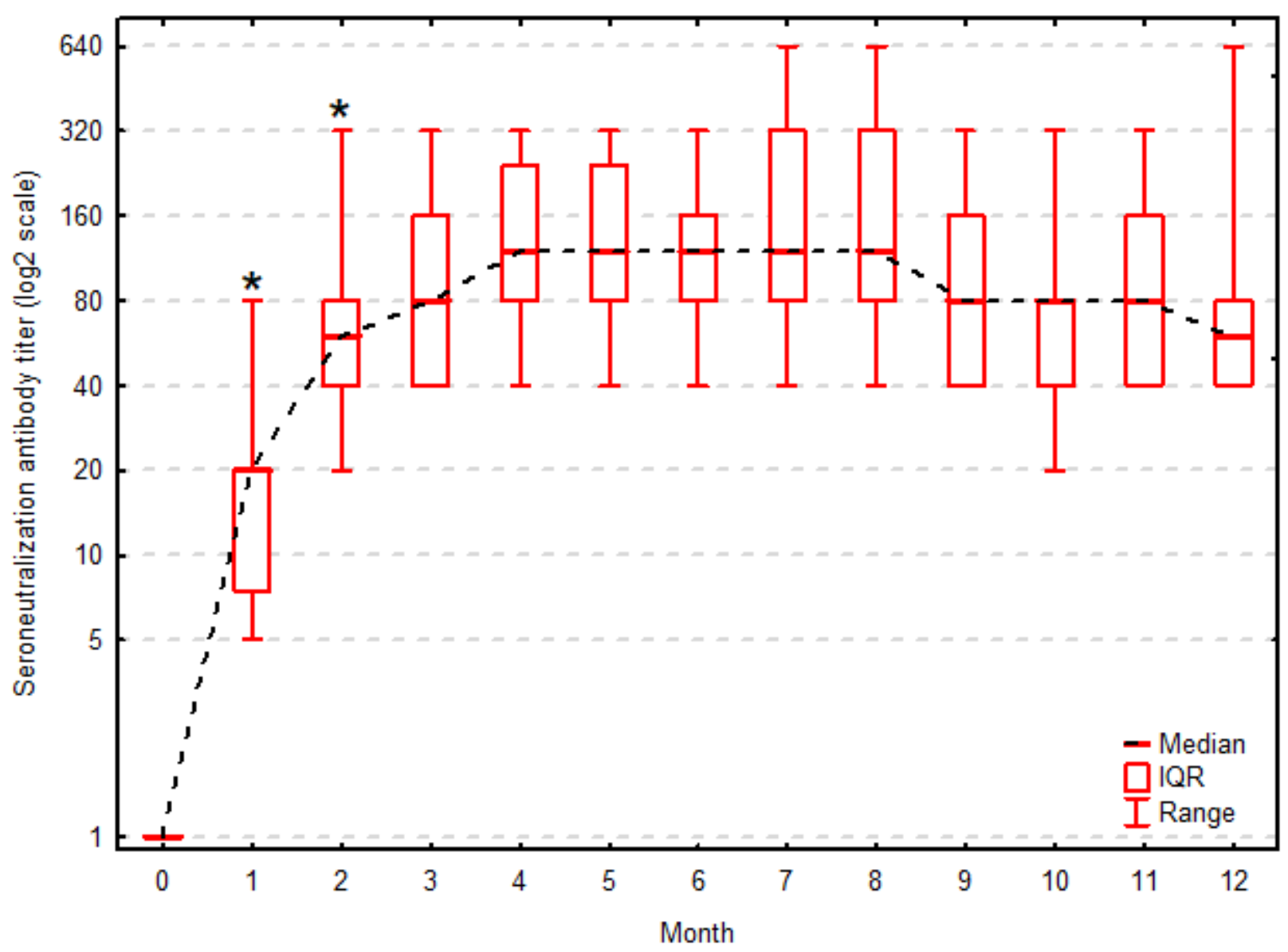

Figure 1

Antibody titers in virus neutralization test during 12 months post vaccination. Antibody titers (on log base 2 transformed scale) are presented as the median, interquartile range (IQR) and range. Asterisk (*) indicates statistically significant increase of the titer compared to the previous one. 


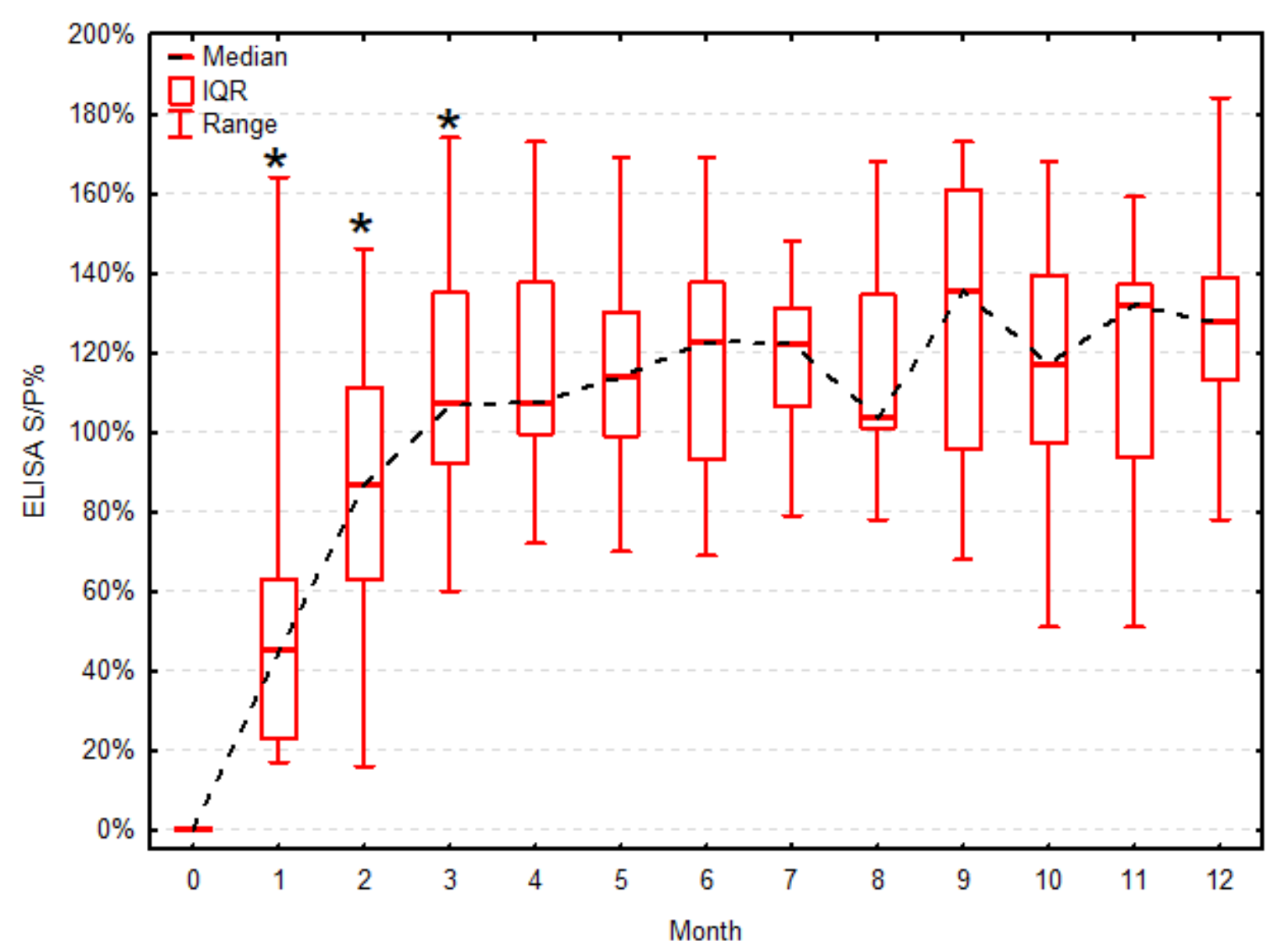

Figure 2

Sample-to-positive control ratio in ELISA during 12 months post vaccination. Sample-to-positive control ratio (S/P\%) in ELISA are presented as the median, interquartile range (IQR) and range. Asterisk (*) indicates statistically significant increase of the titer compared to the previous one. 


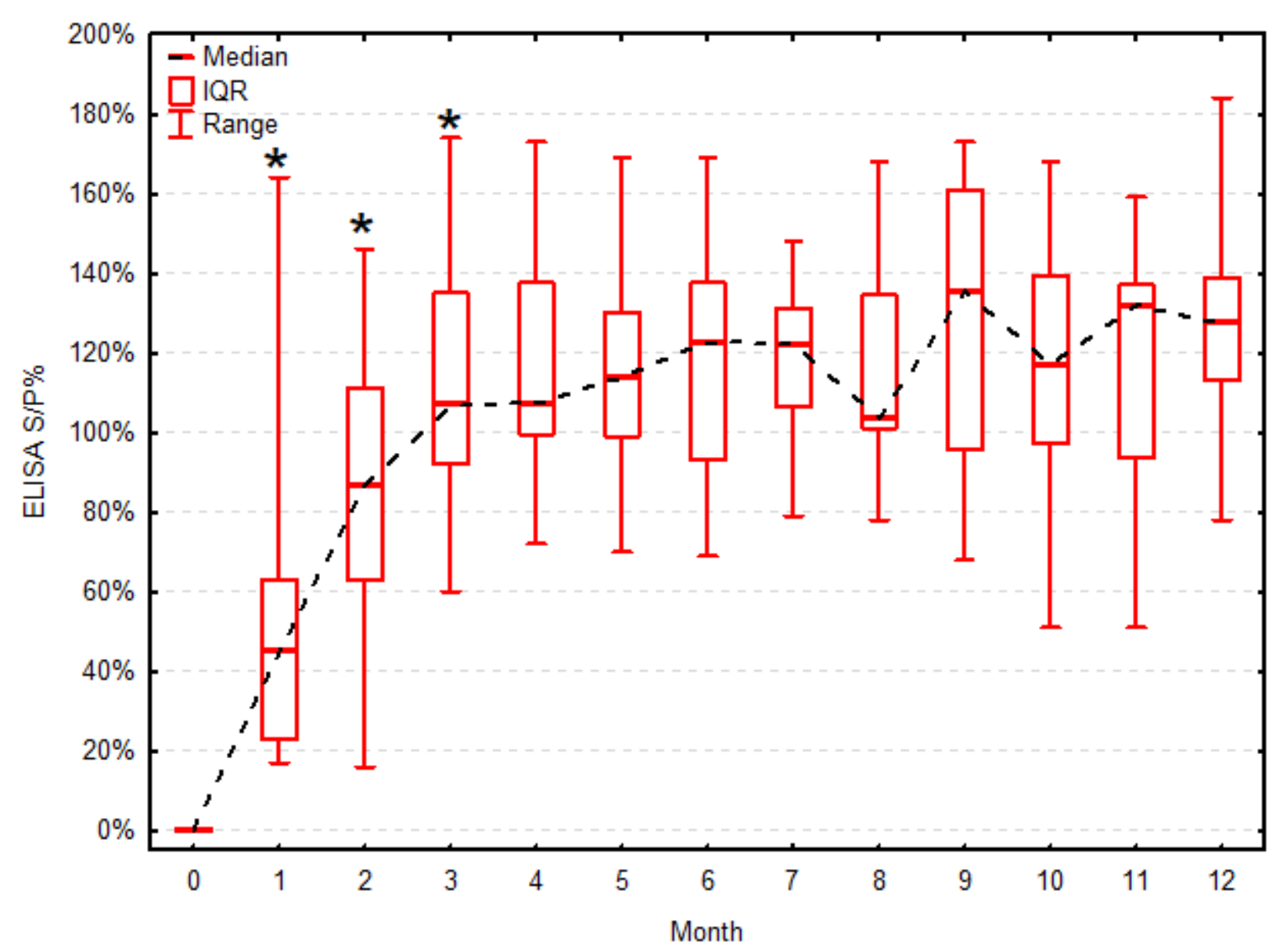

Figure 2

Sample-to-positive control ratio in ELISA during 12 months post vaccination. Sample-to-positive control ratio (S/P\%) in ELISA are presented as the median, interquartile range (IQR) and range. Asterisk (*) indicates statistically significant increase of the titer compared to the previous one. 